\title{
Elämäkeskeisen maailmankäsityksen puolustuspuhe
}

Salonen, Arto O., Kurenlahti, Mikko \& Jaaksi, Ari (2021).

Rakkautta ja valoa. Tie hyvään tulevaisuuteen. Docendo. 272 sivua.

PROFESSORI ARTO O. SALOSEN ja uskonnontutkija Mikko Kurenlahden Rakkautta ja valoa on lukijaan vetoava teos, joka pyrkii avaamaan valoisaa näkymää kestävään tulevaisuuteen. Kirjoittajat haastavat nykyisiä ajattelu- ja toimintatapojamme. Kulutuskeskeinen kulttuurimme haaskaa valtavasti luonnonvaroja, kilpailemme keskenämme ja monet meistä ihmettelevät, mitä oikein etsimme. Menestystä? Hyvää elämää?

Tavoittelemme hyvää elämää kuluttamalla, suorittamalla ja kilpailemalla. Rikkaassa pohjoisessa on materiaalista yltäkylläisyyttä, mutta niin on henkistä pahoinvointiakin. Bruttokansantuote (BKT) kasvaa, mutta samalla elämän edellytykset maapallolla heikkenevät. Aika käy vähiin, kirjoittajat muistuttavat. Elämme muutaman kymmenen vuoden mittaisessa aikaikkunassa, jossa voimme vielä tehdä paljonkin ilmastokriisin vaikutusten lieventämiseksi.

Kirja on olemukseltaan puheenvuoro. Se ei ole tieteellisen viileä katsaus, vaikka kirjoittajien tutkijatausta näkyykin läpi teoksen. Kirjaa voi lukea kaunokirjan tapaan: muodoltaan se on enemmän essee kuin tieteellisesti raportoiva julkaisu. Valokuvaaja Ari Jaaksin kuvat pysäyttävät lukijan hetkittäin, yllättäenkin. Sivua kääntäessä luku ei jatkukaan tekstimuodossa, vaan lukijan eteen avautuu mustavalkoinen kuva tai useampi. Silloin on hetki aika miettiä, mitä juuri lukikaan.

\section{LOHIKÄÄRMEITÄ PÄIN}

Pohdiskelevan, eteenpäin soljuvan teoksen rakenteesta on vaikea muodostaa vaihe vaiheelta etenevää kuvausta. Käytännössä kirja on jaettu kolmeen osaan, mutta ne eivät etene esimerkiksi menneestä tulevaan, vaan tavoitteena lienee kuljettaa lukijaa kirjoittajien ajattelun rytmissä aihepiiristä toiseen. Nopea lukeminen ei sovikaan tälle kirjalle, vaan parempi on lukea muutama kappale ja ajatella hetki.

Tietyt käsitteet ja teemat toistuvat alaluvusta toiseen. Rakkaus, hyvä elämä, kukoistus, täyteys näitä kohti meidän tulisi Salosen ja Kurenlahden mukaan kulkea, mutta reitti voi näyttää pelottavalta. Latinankielinen fraasi "Hic sunt dracones" kirjoitettiin karttoihin niille alueille, joita pidettiin vaarallisina tai joita ei ollut kartoitettu. "Täällä on lohikäärmeitä" kertoo, että alueella on navigoitava vailla tarkempaa tietoa ympäristöstä. Salonen ja Kurenlahti kuitenkin kehottavat ottamaan kurssin kohti uusia vesiä. Se, mitä kohti nyt kuljemme, on nimittäin yksinkertaisesti dystopia, joten on pakko

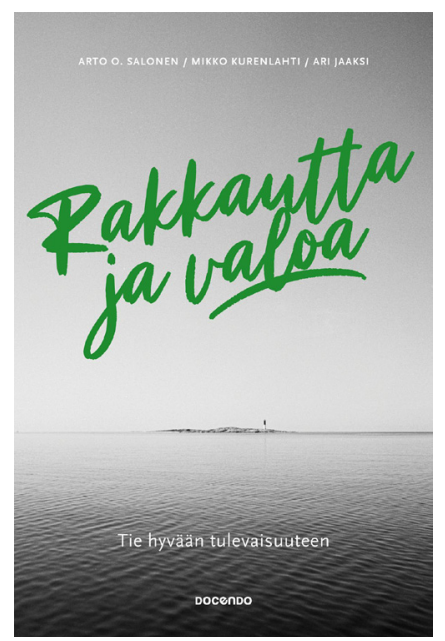

rohkaista mielensä ja kohdata epävarmuus.

Mikä kartoittamattoman tienoon takana sitten odottaa eli mitä nuo rakkaus ja täyteys, hyvä elämä ja kukoistus ovat? Suuria sanoja on vaikea määritellä lyhyesti, ja näille termeille haetaankin sisältöä läpi koko kirjan. Hyvän elämän määrittely on aika- ja kulttuurisidonnaista. Tavoittelemme kuitenkin paljolti samoja asioita: elämän tulee tuntua mielekkäältä, haluamme kokea olevamme arvokkaita ja toivomme, että olisi miellyttävää olla olemassa. Jos nämä kriteerit täyttyvät, voimme kokea täyteyttä ja kukoistaa. Rahalla ei ole niinkään merkitystä. Jo monet tutkimukset ovat osoittaneet, että raha ei lisää onnellisuutta sen jälkeen, kun perusasiat ovat kunnossa. Yhteys muihin on paljon tärkeämpää.

\section{KULUTTAJANA SUURESSA}

KUDELMASSA

Kuluttamista tutkineen Kurenlahden kädenjälki näkyy teoksessa oi- 


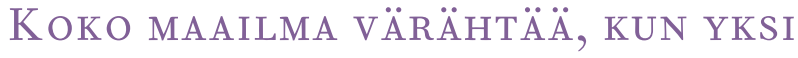

\author{
SUOMALAINEN LAITTAA OSTOSKORIINSA
}

YHDEN AINOAN TUOTTEEN.

valtavina pohdintoina ostamisesta ja tavaroiden omistamisesta. Usein shoppailu tuomitaan tyhjänpäiväisenä hupina, mutta Rakkautta ja valoa antaa kuluttamiselle paljon muitakin merkityksiä. Ostamalla rakentelemme identiteettiämme ja osoitamme välittämistä ja arvostusta. Kuluttamisella voi olla siis jaloja päämääriä, ja teos puhuu jopa pyhyydestä kuluttamisen yhteydessä.

Kuluttajakansalaisina huolehdimme hyvinvointiyhteiskunnasta kuluttamalla mahdollisimman paljon - siten talouden pyörät pyörivät ja bruttokansantuote kasvaa. Tämä ei kuitenkaan ole teoksen mukaan koko totuus. BKT-mittaria ei luotu mittamaan hyvinvointia vaan talouden kokoa. Siitä onkin tullut toimiva mittari hyvinvointia uhkaaville tekijöille. Mitä enemmän kulutamme, sitä enemmän tuhoamme planeettaamme ja heikennämme elinmahdollisuuksiamme saastuttamalla ja köyhdyttämällä luonnon monimuotoisuutta. Bruttokansantuote ei sitä paitsi huomioi ilmaisia palveluksia eikä palkatonta työtä. Sitä kerryttävät rahansiirrot, olivatpa ne inhimillisestä näkökulmasta katsottuina myönteisiä tai kielteisiä. Jopa esimerkiksi auto-onnettomuus kasvattaa bruttokansantuotetta läkärilaskujen ja auton korjauskulujen muodossa.

Teos osoittaa vakuuttavasti, kuinka koko maailma värähtää, kun yksi suomalainen laittaa ostoskoriinsa yhden ainoan tuotteen. Ruuat ja tavarat on tuotettu jossakin, valmistus on vaatinut energiaa. Jokainen kaupan tuotteista on kulkenut monien käsien kautta autoihin tai laivoihin, joita on liikuteltu jollakin polttoaineella. Ostamalla kiinnitymme valtavaan luonnonvarojen ja elävien olentojen verkostoon. Kaikki nämä toiminnot tapahtuvat suljetussa systeemissä. Maahan saapuu vain auringon energiaa, mitään muuta uutta emme saa, vaan kaikki kiertää samassa systeemissä.

\section{ELÄMÄ KESKIÖÖN}

Ari Jaaksin valokuvat ovat pelkistettyjä. Niissä on vain muutama elementti veden lisäksi: puu, kivi tai satunnainen yksinäinen soutaja. Rannattomalta näyttävä aava vesi antaa tilaa katsojan tulkinnoille. Tulevaisuus on tuolla jossakin, horisontissa. Piskuinen puu seisoo rannassa, vuodenajat vaihtuvat sen ympärillä. Kuvia katsoessa on vaikea sanoa, kertovatko ne toivottomuudesta vai ovatko ne täynnä lupausta paremmasta.

Rakkautta ja valoa on tavallaan helppolukuinen teos. Keskeisiä asioita selostetaan osuvin kielikuvin. Esimerkiksi: sisärengas, jota pumpataan ulkorengasta suurem- maksi, selittää planeetan rajojen ja talouskasvun välistä suhdetta osuvammin kuin monikaan donitsitaloustieteen teksti. Lukijana toivoin, että kirjan ydinviesti olisi selitetty yhtä selkeästi. Se käy selväksi, että meidän tulee omaksua elämäkeskeinen maailmankäsitys ja tehdä suuria korjausliikkeitä nimenomaan yhdessä, globaalisti. Talouskasvun välttämättömyys pitää kyseenalaistaa, ihmisten tulee vahvistaa rakkauden hengessä yhteyksiä toisiinsa, kilpailu ja vertailu on kitkettävä pois - kyllä, mutta miten tämä kaikki tehdään? Rakkautta ja valoa antaa ohjenuoria: "Sanoista tekoihin." "Tuotteista palveluihin." "Eläinperäisestä ravinnosta kasviperäiseen".

Teos on suunnattu laajalle yleisölle, ei ainoastaan akateemisille lukijoille. Se puhuttelee nimenomaan yksittäistä kansalaista, vaikka siinä onkin ilahduttavasti myös päättäjile suunnattuja viestejä. Suosittelen teosta kaltaisilleni pessimistisille aikuiskasvatustieteilijöille. Meidän on hyvä tuulettaa ajatuksiamme ja pohtia, voisiko huomenna olla sittenkin paremmin.

\section{ERJA LAAKKONEN}

KT, FM, vapaa tutkija, tuntiopettaja Itä-Suomen yliopisto

(D) https://orcid.org/0000-00030194-4014 